\title{
DAMPAK DIMENSI INDIVIDUAL FINANCIAL LITERACY TERHADAP FINANCIAL INCLUSION PADA MASYARAKAT PEDESAAN
}

\author{
Ricka Ade Putri ${ }^{1}$ \\ Chairil Afandy ${ }^{2}$
}

Manajemen, Fakultas Ekonomi dan Bisnis, Universitas Bengkulu, Indonesia

\begin{abstract}
Abstrak
Penelitian ini bertujuan untuk menganalisis pengaruh dimensi individu dari literasi keuangan terhadap inklusi keuangan. Desain penelitian ini adalah survei dengan kuesioner online. Objek penelitian ini adalah masyarakat di pedesaan Bengkulu. Responden dalam penelitian ini adalah 503 responden. Penelitian ini menggunakan convenience sampling dengan penyaringan. Studi ini mengungkapkan bahwa pengetahuan, sikap, dan perilaku mempengaruhi inklusi keuangan di pedesaan Bengkulu. Sementara keterampilan tidak memengaruhi inklusi keuangan di pedesaan Bengkulu. Penelitian ini juga menemukan bahwa sikap adalah variabel yang memiliki pengaruh terbesar pada inklusi keuangan.

Kata Kunci: sikap, perilaku, inklusi keuangan, literasi keuangan, pengetahuan, keterampilan
\end{abstract}

\begin{abstract}
This study aims to analyze the effect of individual dimensions of financial literacy on financial inclusion. This research design is a survey with an online questionnaire. The object of this research is the people in rural Bengkulu. The respondent in this study was 503 respondents. This study used convenience sampling with screening. This study reveals that knowledge, attitudes, and behaviors influence financial inclusion in rural Bengkulu. While skills do not affect financial inclusion in rural Bengkulu. This research also found that attitude is the variable that has the greatest influence on financial inclusion.
\end{abstract}

Keywords: attitudes, behaviors, financial inclusion, financial literacy, knowledge, skills

Article History: Received: (09-03-2020); Revised: (28-03-2020); and Published: (30-04-2020) Copyright @ 2020 Ricka Ade Putri, Chairil Afandy

How to cite this article: Putri, R.A., dan Afandy, C. (2020). Dampak Dimensi Individual Financial Literacy Terhadap Financial Inclusion Pada Masyarakat Pedesaan. Managament Insight: Jurnal IImiah Manajemen. 15(1), 33-48 


\section{PENDAHULUAN}

Kemiskinan masih menjadi masalah di berbagai negara. Isu sosial yang berkaitan dengan kemiskinan masih menjadi perhatian khusus dalam organisasi kerja sama regional-multilateral seperti G20 (The Group of Twenty), OECD (Organisation for Economic Coperation Development), ASEAN (Association of South East Asia Nations), IMF (International Monetary Fund), ADB (Asian Development Bank) dan The World Bank (www.kemenkeu.go.id). Dalam forum Leaders Summit 2012, G20 meluncurkan Financial Peer Learning Program (FPLP) dan Global Partnership on Financial Inclusion (GPFI) untuk mengatasi permasalahan kemiskinan melalui pemanfaatan lembaga keuangan (www.kemenkeu.go.id). Financial inclusion memainkan peran penting dalam membangun fondasi yang kuat dari infrastruktur keuangan suatu negara, yang nantinya akan memfasilitasi pertumbuhan dan perkembangan ekonomi. Strategi nasional financial inclusion di Indonesia sudah diluncurkan sejak masa pemerintahan Presiden Susilo Bambang Yudoyono (Rakhmindyarto dan Syaifullah, 2013). Strategi ini diharapkan dapat meningkatkan kemampuan masyarakat dalam mengakses sistem keuangan formal sehingga bisa mengatasi masalah kemiskinan dan meningkatkan kesejahteraan rakyat Indonesia.

Survei Nasional Literasi dan Inklusi Keuangan 2016 (SNLIK 2016) menunjukkan bahwa tingkat literasi dan inklusi keuangan di Indonesia mengalami peningkatan sejak tahun 2013. Dimana literasi keuangan Indonesia meningkat dari $21,8 \%$ tahun 2013 menjadi $29,7 \%$ di tahun 2016. Demikian pula pada tingkat inklusi keuangan Indonesia yang meningkat dari 59,7\% di tahun 2013 menjadi 67,8\% di tahun 2016. Namun kesenjangan tingkat literasi dan inklusi di Indonesia masih terlihat pada strata wilayah yakni perkotaan dan pedesaan. Tingkat literasi pada tahun 2016 di perkotaan sebesar $33,2 \%$ sedangkan di pedesaan hanya sebesar 23,9\%. Dan tingkat inklusi keuangan tahun 2016 di perkotaan sebesar 71,2\% sedangkan di pedesaan hanya sebesar 63,2\%. Selain itu, berdasarkan SNLIK 2016 juga terlihat ada 21 provinsi yang memiliki tingkat literasi di bawah rata-rata literasi nasional serta 18 provinsi yang memiliki tingkat inklusi di bawah rata-rata inklusi nasional termasuk provinsi Bengkulu. Persentase literasi keuangan di provinsi Bengkulu hanya sebesar 28,7\% dan inklusi keuangan sebesar $67,3 \%$.

Menurut OECD (2009) kurangnya literasi keuangan sering dikaitkan dengan kurangnya akses pada produk keuangan atau kegagalan untuk menggunakannya bahkan ketika layanan tersebut tersedia (OECD, 2009 dalam Okello et al, 2017). Kemudian, menurut Okello et al (2017) ada empat dimensi individual dari financial literacy yang bisa menjadi penghambat financial inclusion yaitu skill, knowledge, atittude dan behavior. Hal yang sama juga dikemukakan oleh Otoritas Jasa Keuangan (2016) bahwa pembentuk literasi keuangan ialah sikap dan perilaku selain pengetahuan, keterampilan, dan keyakinan yang merupakan upaya peningkatan kualitas pengambilan keputusan dan pengelolaan keuangan individu. 
Beberapa penelitian terdahulu seperti Xu dan Zia (2012); Lusardi dan Tufano (2008); Stango dan Zinman (2009); Cole, Sampson dan Zia (2009); Van Rooji, Lusardi dan Alessi (2007); Nkundabanyanga et al (2014) hanya menggunakan pengetahuan (knowledge) dan keterampilan (skill) sebagai ukuran literasi keuangan sambil menjelaskan akses terhadap layanan keuangan. Namun, mengabaikan penggunaan dimensi fungsional (behavior dan attitude) literasi keuangan. Selain itu, mereka gagal mengisolasi dampak dimensi individual fungsional dan ukuran non-fungsional dari literasi keuangan (knowledge dan skill) dalam menjelaskan financial inclusion (Okello et al, 2017).

\section{TINJAUAN PUSTAKA}

\section{Financial Inclusion}

Menurut Bank Indonesia (2014) financial inclusion ialah hak setiap orang untuk memiliki akses dan layanan penuh dari lembaga keuangan secara tepat waktu, nyaman, informatif dan biaya yang terjangkau, dengan penghormatan penuh kepada harkat dan martabatnya. Layanan keuangan tersedia bagi seluruh segmen masyarakat, dengan perhatian khusus kepada orang miskin, orang miskin produktif, pekerja migran dan penduduk di daerah terpencil.

OJK (2017) dan Bank Indonesia (2014) sepakat bahwa ada empat dimensi financial inclusion yaitu ketersediaan/akses lembaga keuangan, penggunaan produk dan layanan jasa keuangan, peningkatan kualitas baik kualitas penggunaan produk dan layanan jasa keuangan maupun kualitas produk dan layanan jasa keuangan itu sendiri, serta peningkatan kesejateraan masyarakat melalui layanan keuangan. Menurut Bank Indonesia (2014) dimensi akses (access) mengukur kemampuan penggunaan jasa keuangan formal dalam hal keterjangkauan fisik dan harga. Secara lebih spesifik OJK (2017) mengartikan dimensi ini sebagai ketersediaan infrastruktur agar masyarakat dapat menjangkau baik lembaga, produk dan layanan jasa keuangan yang bersifat formal. Indikator dari dimensi akses ialah: (1) Ketersediaan infrastruktur lembaga keuangan; (2) Jarak lembaga keuangan; dan (3) Keterjangkauan biaya menuju lembaga keuangan.

Dimensi penggunaan (usage) mengukur kemampuan penggunaan aktual produk dan jasa keuangan (Bank Indonesia, 2014). Penggunaan ini berkaitan berkaitan dengan kepemilikan produk keuangan seperti rekening tabungan dan pinjaman, keteraturan, frekuensi dan lama penggunaan produk keuangan oleh masyarakat. Dari definisi tersebut maka indikator dari dimensi penggunaan ialah: (1) Kepemilikan rekening bank; (2) Penggunaan produk pinjaman atau kredit bank; (3) Keteraturan penggunaan produk perbankan; (4) Frekuensi penggunaan produk; dan (5) Lama waktu penggunaan produk perbankan.

Dimensi kualitas (quality) mengukur apakah atribut produk dan jasa keuangan telah memenuhi kebutuhan pelanggan (Bank Indonesia, 2014). OJK (2017) 
memberikan penjelasan yang lebih rinci bahwa dimensi kualitas merupakan kondisi dimana produk dan layanan jasa keuangan dapat memberikan manfaat yang besar bagi masyarakat dengan menawarkan produk yang sesuai dengan harapan mereka. Indikator dari dimensi kualitas ialah: (1) Kesesuaian produk perbankan dengan kebutuhan masyarakat; (2) Kenyamanan dalam menggunakan produk; dan (3) Keamanan dalam menggunakan produk perbankan.

Dimensi kesejateraan (welfare) mengukur dampak layanan keuangan terhadap tingkat kehidupan pengguna jasa keuangan (Bank Indonesia, 2014). Indikator dari dimensi kesejahteraan ialah: (1) Kemudahan dalam membayar tagihan; (2) Mempermudah aktivitas sehari-hari; (3) Meningkatkan kesejahteraan hidup masyarakat melalui produk perbankan; (4) Mengembangkan usaha masyarakat; (5) Meningkatkan kemampuan pengelolaan keuangan.

\section{Dimensi Individual dari Financial Literacy}

Huston (2010) berpendapat bahwa financial literacy memiliki dua dimensi yakni pemahaman yang mewakili pengetahuan keuangan pribadi dan kemampuan dalam penggunaan jasa keuangan yang mengacu pada pengelolaan pengetahuan keuangan pribadi. Selain pengetahuan dan keterampilan keuangan, ada dimensi lain dalam financial literacy yaitu sikap dan perilaku terhadap keuangan (Holzmann, 2010). Okello et al (2017) menemukan bahwa pengetahuan, keterampilan, sikap, dan perilaku keuangan mampu memengaruhi financial inclusion.

\section{Knowledge}

Pengetahuan keuangan digunakan untuk mengukur peringkat penilaian diri individu tentang hal-hal keuangan terkait pengelolaan keuangan pribadi, menetapkan tujuan keuangan, perencanaan keuangan, rekening bank, produk atau layanan bank dan lain-lain (Tustin, 2010). Lusardi (2008) mengatakan bahwa pengetahuan keuangan yang rendah dapat mengakibatkan tingkat perencanaan keuangan yang rendah, tingkat akumulasi aset yang rendah dan tingkat penggunaan layanan keuangan alternatif yang tinggi. Knowledge menawarkan pemahaman tentang konsep keuangan (Braunstein dan Welch (2002) sehingga menghindarkan individu dari menggunakan layanan keuangan non-standar, seperti misalnya pinjaman rentenir yang cenderung merugikan masyarakat dengan bunga yang tidak terkendali.

Financial literacy memfasilitasi proses pengambilan keputusan, yang memperbaiki tingkat tabungan dan kelayakan kredit masyarakat dengan memberdayakan ekonomi dan sosial mereka (Kefela, 2010). Selain itu, literasi keuangan berguna untuk meningkatkan skill dan knowledge mengenai lembaga keuangan (Atkinson dan Messy, 2013). Hal ini nantinya akan berdampak pada financial inclusion karena masyarakat yang memiliki pengetahuan dan keterampilan akan lebih mudah mengakses jasa dari lembaga keuangan. 
H1 : Knowledge berpengaruh terhadap financial inclusion di pedesaan Bengkulu.

\section{Skill}

Menurut Okello et al (2017), masyarakat membutuhkan tingkat pemahaman dan keterampilan financial tertentu untuk mengevaluasi dan membandingkan produk keuangan, seperti rekening bank, produk tabungan, pilihan kredit dan pinjaman dan instrumen pembayaran. Skill didefinisikan sebagai bagian dari literasi keuangan yang digunakan untuk mengelola sumber daya keuangan secara efektif (Hussain et al, 2018). Holzmann (2010) mengemukakan bahwa keterampilan financial yang terkait dengan pelatihan langsung pada masyarakat di negara berkembang dapat membantu mereka memiliki kapasitas untuk membuat rencana tabungan.

Cohen dan Nelson (2011) mengatakan bahwa dorongan financial literacy memungkinkan masyarakat membuat keputusan keuangan yang lebih tepat sasaran dengan kesadaran tinggi mengenai masalah keuangan dan pilihan ditambah dengan keterampilan keuangan dasar. Financial literacy dapat memfasilitasi penggunaan produk yang efektif, yang penting untuk financial inclusion.

$\mathrm{H} 2$ : Skill berpengaruh terhadap financial inclusion di pedesaan Bengkulu.

\section{Atittude}

Atittude diartikan sebagai keadaan pikiran, pendapat serta penilaian seorang individu terkait keuangan (Pankow, 2003). Kurangnya pengetahuan dan keterampilan tentang cara kerja produk keuangan serta biaya akses yang mahal dapat menciptakan sikap buruk dalam konsumsi produk dan layanan keuangan (Okello et al, 2017).

Cohen dan Nelson (2011) mengatakan bahwa pemahaman yang luas tentang opsi dan prinsip keuangan, akan membangun sikap yang mendukung penggunaan sumber daya keuangan. Sikap yang ditanamkan melalui literasi menyebabkan masyarakat berkeinginan untuk merencanakan keuangan yang kemudian akan berdampak pada rencana tabungan dan pinjaman (Willis, 2008). Okello et al (2017) menemukan bahwa sikap keuangan individu mempengaruhi pemilihan dan penggunaan produk keuangan mereka. Konsumsi dan penggunaan produk keuangan oleh individu di negara berkembang secara langsung terkait dengan sikap dan bergantung pada kepercayaan pada lembaga keuangan dan produk yang tersedia. H3 : Attitude berpengaruh terhadap financial inclusion di pedesaan Bengkulu.

\section{Behavior}

Behavior merupakan perilaku seseorang ketika berurusan dengan uang yang diyakini memiliki kontribusi pada kesejahteraan finansialnya (Chaulagain, 2017). Behavior seringkali juga diartikan sebagai pengambilan keputusan keuangan individu dan rumah tangga (Okello et al, 2017). Pada negara-negara berkembang, di mana mayoritas penduduk tidak memiliki akses terhadap layanan keuangan formal, program 
financial literacy dan intervensi mampu meningkatkan penggunaan produk seperti rekening tabungan dan asuransi (Xu dan Zia, 2012). Hal ini sesuai dengan Social Learning Theory bahwa perilaku turut dipengaruhi oleh lingkungan dan cognitive. Asumsinya bahwa di Negara berkembang yang mayoritas tidak memiliki akses terhadap layanan keuangan formal menunjukkan bahwa tingkat inklusi yang rendah. Lingkungan seperti ini kemudian akan mempengaruhi cognitive dan perilaku individu yang cenderung enggan menggunakan layanan keuangan formal. Maka dari itu perlu diterapkan program financial literacy.

Hudson dan Bush (2008) mengartikan literasi keuangan sebagai kemampuan untuk memahami kondisi keuangan dan konsep-konsep keuangan serta untuk mengubah pengetahuan itu secara tepat ke dalam perilaku. Pelatihan financial literacy terbukti mampu meningkatkan pengetahuan keuangan yang mempengaruhi perilaku keuangan masyarakat (Jappelli, 2010). Selain itu literasi keuangan juga mendorong penghematan dengan meningkatkan kesadaran dan pengetahuan tentang produk keuangan dan mempengaruhi perilaku yang berdampak pada peningkatan financial inclusion seperti keputusan mengambil tabungan dan asuransi, perencanaan pensiun, partisipasi pasar, kepemilikan rekening bank, investasi, pengelolaan hutang dan praktik keuangan (Braunstein dan Welch, 2002). Perilaku ini menjadi hal yang sangat penting bagi masyarakat di negara berkembang (Braunstein dan Welch, 2002).

H4 : Behavior berpengaruh terhadap financial inclusion di pedesaan Bengkulu.

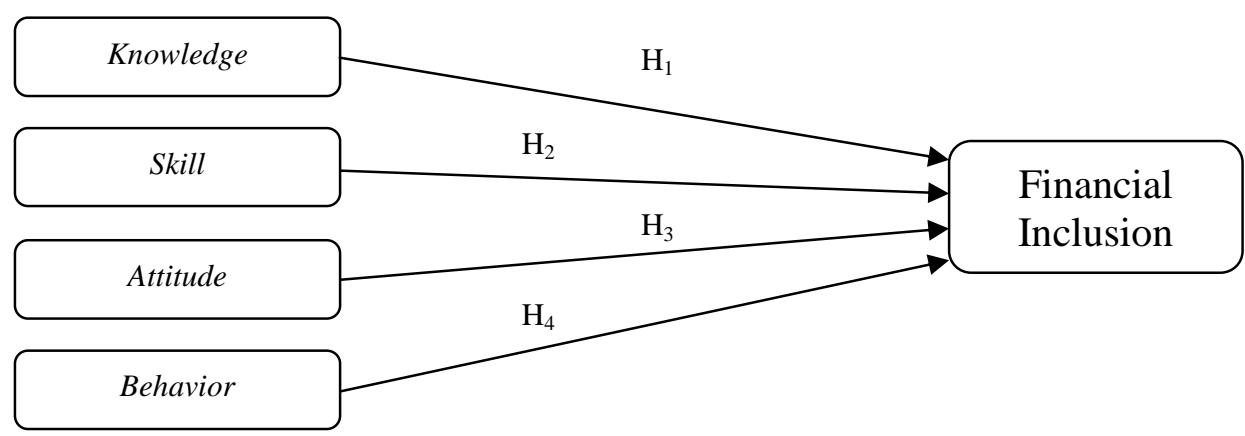

Gambar 1. Rerangka Analisis

\section{METODE PENELITIAN}

Penelitian ini merupakan penelitian kuantitatif dimana terdapat pengujian hipotesis. Penelitian ini menggunakan desain survei, yaitu penelitian yang mengambil sampel secara langsung dari populasi. Untuk memecahkan masalah maka dilakukan uji hipotesis. Studi yang termasuk dalam pengujian hipotesis biasanya menjelaskan sifat hubungan tertentu atau kebebasan (independensi) dua atau lebih faktor dalam satu situasi (Sekaran, 2009).

Sampel adalah sebagian dari populasi. Sampel terdiri atas sejumlah anggota yang dipilih dari populasi. Dengan mempelajari sampel, maka peneliti akan mampu 
menarik kesimpulan yang dapat digeneralisasikan terhadap populasi penelitian (Sekaran, 2009). Teknik penarikan sampel yang digunakan dalam penelitian ini adalah non probability sampling. Karena sampel harus bertempat tinggal di pedesaan yang terletak dalam cakupan Provinsi Bengkulu maka teknik yang digunakan ialah convenience sampling dengan screening. Convenience sampling merupakan pengumpulan sampel dari populasi yang dengan senang hati bersedia memberikan informasi yang dibutuhkan peneliti (Sekaran, 2009). Sedangkan screening yang digunakan berupa pertanyaan yang berkaitan dengan wilayah atau daerah tempat tinggal responden, apakah tinggal di pedesaan atau tidak dan apakah pedesaan tersebut berada di Provinsi Bengkulu. Populasi dalam penelitian ini adalah masyakat pedesaan di Propinsi Bengkulu dengan sampel sebanyak 503 orang responden. Jenis data penelitian ini adalah data primer. Metode pengumpulan data menggunakan kuesioner online.

Dalam penelitian ini dilakukan analisis deskriptif untuk mengetahui dan menginterpretasikan data mengenai demografi responden, menentukan hubungan demografi terhadap variabel penelitian dan menentukan tanggapan responden terhadap variabel penelitian. Sedangkan analisis data seperti uji validitas dan uji reliabilitas; inner model dan outer model; dan pengujian hipotesis dilakukan dengan menggunakan program SmartPLS. Operasionalisasi variabel penelitian ini dapat dilihat pada Tabel 1.

Tabel 1. Operasional Variabel

\begin{tabular}{|c|c|c|c|c|}
\hline Variabel & Definisi & Dimensi & Indikator & Skala \\
\hline $\begin{array}{l}\text { Financial } \\
\text { Inclusion }\end{array}$ & $\begin{array}{l}\text { Financial inclusion } \\
\text { adalah hak setiap } \\
\text { orang (masyarakat } \\
\text { pedesaan) untuk } \\
\text { memiliki akses dan } \\
\text { layanan penuh dari } \\
\text { lembaga keuangan } \\
\text { secara tepat waktu, } \\
\text { nyaman, informatif, } \\
\text { dan terjangkau } \\
\text { biayanya, dengan } \\
\text { penghormatan penuh } \\
\text { kepada harkat dan } \\
\text { martabatnya. }\end{array}$ & Kualitas & $\begin{array}{l}\text { 1. Ketersediaan infrastruktur lembaga } \\
\text { keuangan. } \\
\text { 2. Jarak lembaga keuangan. } \\
\text { 3. Keterjangkauan biaya menuju lembaga } \\
\text { keuangan. } \\
\text { 1. Kepemilikan rekening perbankan. } \\
\text { 2. Penggunaan produk pinjaman atau kredit } \\
\text { bank. } \\
\text { 3. Keteraturan penggunaan produk } \\
\text { perbankan. } \\
\text { 4. Frekuensi penggunaan produk. } \\
\text { 5. Lama waktu penggunaan produk } \\
\text { perbankan. } \\
\text { 1. Kesesuaian produk perbankan dengan } \\
\text { kebutuhan masyarakat. } \\
\text { 2. Kenyamanan dalam menggunakan } \\
\text { produk. } \\
\text { 3. Keamanan dalam menggunakan produk } \\
\text { perbankan. } \\
\text { 1. Kemudahan dalam membayar tagihan } \\
\text { 2. Mempermudah aktivitas sehari-hari. } \\
\text { 3. Peningkatan kesejahteraan hidup } \\
\text { masyarakat melalui produk perbankan. } \\
\text { 4. Pengembangkan usaha masyarakat. } \\
\text { 5. Meningkatkan kemampuan pengelolaan } \\
\text { keuangan. }\end{array}$ & Interval \\
\hline
\end{tabular}




\begin{tabular}{|c|c|c|c|}
\hline Variabel & Dimensi & Indikator & Skala \\
\hline \multirow{3}{*}{ Knowledge } & Knowledge merupakan bagian dari & 1. Pengetahuan dasar tentang keuangan. & \\
\hline & $\begin{array}{l}\text { literasi keuangan yang menawarkan } \\
\text { pemahaman yang lebih baik tentang }\end{array}$ & 2. Pengetahuan tentang lembaga keuangan. & \\
\hline & $\begin{array}{c}\text { konsep keuangan dan dengan demikian } \\
\text { mendorong pihak yang tidak berafiliasi } \\
\text { untuk menghindari layanan keuangan } \\
\text { non-standar. }\end{array}$ & & Rasio \\
\hline Skill & $\begin{array}{l}\text { Skill merupakan keterampilan seseorang } \\
\text { untuk mengelola sumber daya keuangan } \\
\text { secara efektif. }\end{array}$ & $\begin{array}{l}\text { 1. Keterampilan keuangan terkait pilihan } \\
\text { produk keuangan. } \\
\text { 2. Keterampilan dalam menghitung suku } \\
\text { bunga. }\end{array}$ & Rasio \\
\hline Atittude & $\begin{array}{c}\text { Atittude diartikan sebagai keadaan } \\
\text { pikiran, pendapat serta penilaian seorang } \\
\text { individu terkait keuangan . }\end{array}$ & $\begin{array}{l}\text { 1. Sikap terhadap perencanaan keuangan. } \\
\text { 2. Sikap terhadap produk keuangan. } \\
\text { 3. Pandangan terhadap perbankan. }\end{array}$ & Interval \\
\hline Behavior & $\begin{array}{l}\text { Behavior merupakan perilaku seseorang } \\
\text { ketika berurusan dengan uang yang } \\
\text { diyakini memiliki kontribusi pada } \\
\text { kesejahteraan finansialnya. }\end{array}$ & $\begin{array}{l}\text { 1. Perilaku dalam penganggaran. } \\
\text { 2. Perilaku membayar tagihan secara tepat } \\
\text { waktu. } \\
\text { 3. Perilaku menabung. }\end{array}$ & Interval \\
\hline
\end{tabular}

Sumber: Bank Indonesia (2014); Okello et al (2017); Braunstein dan Welch (2002); Hussain et al (2018); Pankow (2014); Chaulagain (2017)

Abdillah dan Jogiyanto (2015) menyatakan bahwa role of thumb yang digunakan untuk validitas konvergen adalah outer loading harus lebih besar dari 0,70, nilai communality harus lebih besar dari 0,50 dan nilai Average Variance Extracted (AVE) harus lebih besar dari 0,50. Skor loading antara 0,50-0,70 dapat dipertahankan atau tidak perlu dihapus selama skor AVE dan communality indikator tersebut lebih besar dari 0,50. Berdasarkan Tabel Outer Loading (lihat lampiran A), masih ada nilai outer loading yang berada dibawah 0,7 namun masih dapat dipertahankan karena nilai AVE dan Communality lebih besar dari 0,50 (lihat lampiran B). Sehingga dapat disimpulkan bahwa semua konstruk penelitian telah memenuhi syarat convergen validity. Berdasarkan nilai cross loading (lihat lampiran C), diketahui bahwa seluruh indikator memiliki nilai cross loading yang paling tinggi pada konstruk atau variabel laten yang diwakilinya jika dibandingkan dengan nilai cross loading pada variabel laten lain. Sehingga dapat disimpulkan bahwa setiap variabel laten telah memenuhi syarat discriminant validity.

Menurut Hair et al (2008) rule of thumb yang digunakan dalam uji reliabilitas yaitu nilai composite reliability harus lebih besar dari 0,7 , nilai cronbach's alpha harus lebih besar dari 0,6 dan nilai 0,6 masih dapat diterima. Berdasarkan tabel cronbach's alpha dan composite reliability (lihat lampiran D) dapat diketahui bahwa semua nilai berada di atas 0,7 sehingga dapat disimpulkan bahwa semua konstruk variabel telah memenuhi syarat reliabilitas.

\section{HASIL PENELITIAN}

\section{Analisis Deskriptif}

Analisis deskriptif dilakukan untuk mengetahui dan menginterpretasikan data mengenai demografi responden. Analisis deskriptif dilakukan menggunakan software SPSS. Berdasarkan hasil kuesioner yang telah diolah dapat diketahui bahwa mayoritas 
responden bertempat tinggal di kabupaten Rejang Lebong. Berikut ini adalah urutan jumlah responden berdasarkan kabupaten tempat tinggalnya: (1) Rejang Lebong 130 orang, (2) Bengkulu Utara 57 orang, (3) Kaur 53 orang, (4) Bengkulu Tengah 49 orang, (5) Muko-muko 49 orang, (6) Seluma 42 orang, (7) Lebong 42 orang, (8) Bengkulu Selatan 41 orang dan (9) Kepahiang 40 orang.

Selanjutnya jika dilihat dari gender, mayoritas responden dalam penelitian ini ialah perempuan yakni sebanyak 339 orang, sedangkan sisanya sebanyak 164 orang adalah laki-laki. Kemudian jika dilihat dari segi usia mayoritas responden dalam penelitian ini berusia 19-25 tahun yaitu sebanyak 349 orang. Dan jika ditinjau dari segi pendidikan mayoritas responden berpendidikan terakhir SMA/SMK yakni sebanyak 370 orang. Di tingkat kedua ternyata responden dalam penelitian ini memiliki pendidikan terakhir sebagai sarjana yaitu 114 orang. Lalu sisanya 2 orang tamat SMP dan 17 orang memilih 'other' yang artinya pendidikan mereka tidak ada dalam pilihan yang disediakan dengan rincian sebagai berikut: 3 orang D1 Komputer, 10 orang D3 Keperawatan dan 4 orang D3 Kebidanan.

Dalam penelitian ini dilakukan crosstabs guna menghitung penyilangan faktor demografi yaitu gender, usia dan pendidikan terhadap Financial Literacy. Crosstabs dilakukan menggunakan program SPSS. Persilangan antara faktor demografi dengan Financial Literacy dilakukan untuk memperoleh gambaran jika satu konstruk dikaitkan dengan konstruk lainnya. Crosstabs penting dilakukan agar saran yang diberikan lebih efektif dalam meningkatkan literasi keuangan masyarakat.

Dari tabel hasil crosstab diperoleh kesimpulan bahwa responden yang berpendidikan terakhir SMP, berusia 19-25 tahun dan berjenis kelamin perempuan memiliki persentase financial literacy berkategori rendah yang paling besar. Hal ini sesuai dengan hasil compare mean sebelumnya yang menunjukkan bahwa semakin rendah pendidikan seseorang maka semakin rendah pula tingkat literasi keuangannya, kemudian semakin muda usia seseorang makan semakin rendah pula tingkat literasi keuangannya. Selain itu hasil compare mean sebelumnya juga menunjukkan bahwa perempuan memiliki tingkat literasi yang lebih rendah dibandingkan dengan laki-laki, hal ini juga sesuai dengan hasil temuan pengolahan crosstab.

Sedangkan responden yang berpendidikan terakhir Sarjana berusia 36-45 tahun dan berjenis kelamin perempuan memiliki persentase financial literacy tinggi yang paling besar. Hal ini juga sesuai dengan hasil temuan pada compare mean sebelumnya yang menunjukkan bahwa semakin tinggi pendidikan seseorang maka semakin tinggi pula tingkat literasi keuangannya dan semakin matang usia seseorang makan semakin tinggi pula tingkat literasi keuangannya. 
Tabel 2. Crosstabs antara Demografi Responden dengan Financial Literacy

\begin{tabular}{|c|c|c|c|c|c|c|}
\hline \multirow{2}{*}{ Pendidikan Terakhir } & \multirow{2}{*}{ Usia } & & & \multicolumn{3}{|c|}{ Financial Literacy } \\
\hline & & & & Rendah & Sedang & Tinggi \\
\hline \multirow[t]{2}{*}{ SMP } & $19-25$ thn & Gender & Perempuan & $50 \%$ & $50 \%$ & \\
\hline & & & Laki-laki & & & \\
\hline \multirow[t]{6}{*}{ SMA/SMK } & $19-25$ thn & Gender & Perempuan & $3,0 \%$ & $36,4 \%$ & $33,3 \%$ \\
\hline & & & Laki-laki & $1,5 \%$ & $11,4 \%$ & $14,4 \%$ \\
\hline & $26-35$ thn & & Perempuan & & $23,2 \%$ & $24,6 \%$ \\
\hline & & & Laki-laki & $1,4 \%$ & $10,1 \%$ & $40,6 \%$ \\
\hline & $36-45$ thn & & Perempuan & & $18,9 \%$ & $32,4 \%$ \\
\hline & & & Laki-laki & & $16,2 \%$ & $32,4 \%$ \\
\hline \multirow[t]{6}{*}{ Sarjana } & $19-25$ thn & Gender & Perempuan & $5,9 \%$ & $27,9 \%$ & $35,3 \%$ \\
\hline & & & Laki-laki & $1,5 \%$ & $14,7 \%$ & $14,7 \%$ \\
\hline & $26-35$ thn & & Perempuan & $7,3 \%$ & $19,5 \%$ & $39,0 \%$ \\
\hline & & & Laki-laki & & $9,8 \%$ & $24,4 \%$ \\
\hline & $36-45$ thn & & Perempuan & & $40,0 \%$ & $60,0 \%$ \\
\hline & & & Laki-laki & & & \\
\hline Other: & $19-25$ thn & Gender & Perempuan & $5,9 \%$ & $29,4 \%$ & $47,1 \%$ \\
\hline \multicolumn{7}{|l|}{ D1 Komputer } \\
\hline \multicolumn{3}{|l|}{ D3 Keperawatan } & Laki-laki & & $11.8 \%$ & $5.9 \%$ \\
\hline D3 Kebidanan & & & LdKI-IdKI & & $11,0 \%$ & $3,9 \%$ \\
\hline
\end{tabular}

Sumber: Hasil Penelitian, 2019

\section{Uji Hipotesis}

Penelitian ini memiliki empat hipotesis yang semuanya merupakan hipotesis two-tailed yakni hipotesis yang belum ditentukan arahnya. Pengujian hipotesis dilakukan dengan perhitungan bootstrapping pada SmartPLS 2.0.m. Pengujian dengan bootstrapping ini dimaksudkan untuk meminimalkan masalah ketidaknormalan data penelitian. Menurut Hair et al (2010) metode bootsrapping adalah metode berbasis resampling data sampel dengan harapan sampel tersebut dapat lebih mewakili data populasi sebenarnya. 


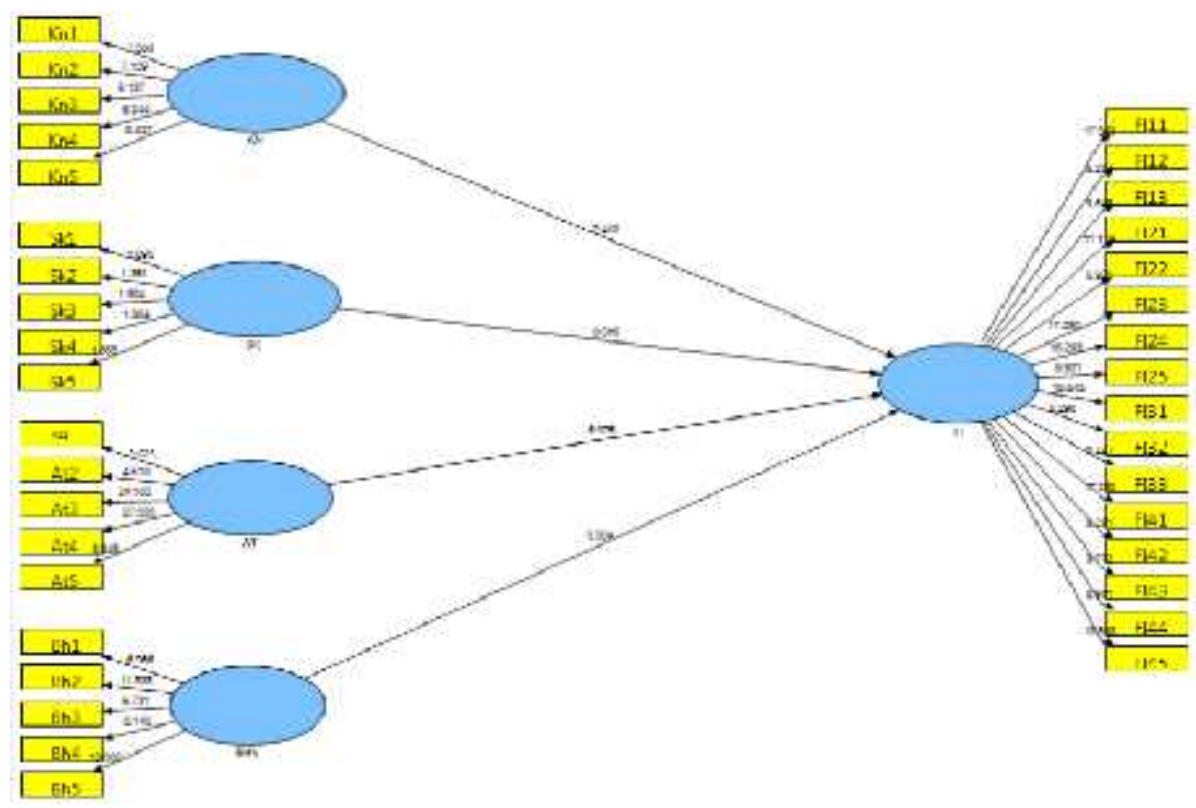

Gambar 2. Output Bootstrapping

Dasar yang digunakan dalam menguji hipotesis yaitu nilai yang terdapat pada output total effect. Adapun Output estimasi untuk pengujian model struktural ditunjukan pada Tabel 2 berikut ini:

Tabel 3. Output Total Effect

\begin{tabular}{llllll}
\hline & $\begin{array}{l}\text { Original } \\
\text { Sample (O) }\end{array}$ & $\begin{array}{l}\text { Sample Mean } \\
(\mathrm{M})\end{array}$ & $\begin{array}{l}\text { Standard Deviation } \\
\text { (STDEV) }\end{array}$ & $\begin{array}{l}\text { Standard Error } \\
\text { (STERR) }\end{array}$ & $\begin{array}{l}\text { T } \\
\text { (|O/STERR ) }\end{array}$ \\
\hline $\mathrm{AT}$-> FI & 0,491007 & 0,477071 & 0,082172 & 0,082172 & 5,975377 \\
$\mathrm{BHV}->\mathrm{FI}$ & 0,287493 & 0,307043 & 0,087009 & 0,087009 & 3,304161 \\
$\mathrm{KN}->\mathrm{FI}$ & 0,170813 & 0,171193 & 0,070890 & 0,070890 & 2,409552 \\
$\mathrm{SK}->\mathrm{FI}$ & $-0,001240$ & 0,013462 & 0,076368 & 0,076368 & 0,016242 \\
\hline
\end{tabular}

Keterangan:

AT : Attitude, BHV: Behavior, KN: Knowledge, SK: Skill, FI: Financial Inclusion

Berdasarkan hasil total effects pada Tabel 3, pengujian hipotesis dilakukan dengan membandingkan nilai t-statistic yaitu harus lebih besar dari nilai $t$-table yaitu 1,96 untuk dapat membuktikan hipotesis tersebut diterima. Hasil pengujian hipotesis pertama dalam penelitian ini menunjukan bahwa nilai $t$-statistic knowledge yakni 2,41 lebih besar dari nilai $t$-table yaitu $1,96(2,41>1,96)$. Dengan demikian, dapat disimpulkan bahwa knowledge berpengaruh postitif terhadap financial inclusion di pedesaan Bengkulu. Sedangkan pengujian hipotesis kedua dalam penelitian ini menunjukan bahwa nilai $t$-statistic skill yakni 0,01 lebih kecil dari nilai $t$-table yaitu $1,96(0,01>1,96)$. Dengan demikian, dapat disimpulkan bahwa skill tidak berpengaruh terhadap financial inclusion di pedesaan Bengkulu.

Hasil pengujian hipotesis ketiga dalam penelitian ini menunjukan bahwa nilai $t$ statistic attitude yakni 5,97 lebih besar dari nilai $t$-table yaitu $1,96(5,97>1,96)$. Hasil Dampak Dimensi Individual Financial Literacy Terhadap Financial Inclusion Pada Masyarakat Pedesaan 
pengujian hipotesis keempat dalam penelitian ini menunjukan bahwa nilai $t$-statistic behavior yakni 3,30 lebih besar dari nilai t-table yaitu $1,96(3,30>1,96)$. Dengan demikian, sejalan dengan knowledge dapat disimpulkan bahwa attitude, dan behavior juga memberikan pengaruh positif terhadap financial inclusion di pedesaan Bengkulu

\section{PEMBAHASAN}

Hasil pengujian hipotesis menunjukkan bahwa hipotesis pertama dapat diterima sehingga disimpulkan bahwa dimensi individual financial literacy yakni knowledge memiliki pengaruh positif terhadap financial inclusion di pedesaan Bengkulu. Pengetahuan keuangan digunakan untuk mengukur penilaian individu tentang keuangan yang terkait pengelolaan keuangan pribadi, menetapkan tujuan keuangan, perencanaan keuangan, rekening bank, produk atau layanan bank dan lainlain (Tustin, 2010). Kemudian Lusardi (2008) mengatakan bahwa pengetahuan keuangan yang rendah dapat mengakibatkan tingkat perencanaan keuangan yang lebih rendah dan tingkat penggunaan layanan keuangan alternatif yang lebih tinggi.

Xu \& Zia (2012) berpendapat bahwa di negara berkembang, pengetahuan yang dibangun melalui program literasi keuangan mampu meningkatkan pengambilan produk seperti rekening tabungan dan asuransi. Literasi keuangan menyebabkan peningkatan kesadaran individu yang besar dan signifikan tentang produk dan layanan keuangan yang tersedia bagi mereka, (Okello et al, 2017). Pengetahuan keuangan yang baik akan mempengaruhi pengambilan keputusan terkait produk keuangan, yang kemudian memperbaiki tingkat tabungan dan kelayakan kredit masyarakat (Kefela, 2010). Selain itu, peningkatan pengetahuan mengenai lembaga keuangan akan berdampak pada financial inclusion karena masyarakat yang memiliki pengetahuan akan lebih mudah mengakses jasa dari lembaga keuangan (Atkinson dan Messy, 2013).

Hipotesis kedua dalam penelitian ini ditolak, hal ini menunjukkan bahwa tidak ada pengaruh antara skill keuangan individu di pedesaan Bengkulu terhadap financial inclusion. Hasil temuan dalam hipotesis kedua ini mendukung temuan dari Okello et al (2017) yang menyatakan bahwa tidak ada hubungan antara skill terhadap financial inclusion. Pola sampel dalam penelitian Okello et al tahun 2017 memiliki beberapa kemiripan dengan pola sampel dalam penelitian ini antara lain yaitu sama-sama menggunakan sampel dari masyarakat di pedesaan yang berada di Negara berkembang.

Ada beberapa alasan yang menyebabkan skill tidak berpengaruh terhadap financial inclusion. Pertama, jika dilihat dari hasil persentase tingkat skill responden, ada 59\% masyarakat yang memiliki skill tinggi namun masyarakat yang memiliki skill rendah juga masih cukup banyak yaitu 38,8\%. Sedangkan tanggapan responden terhadap variabel financial inclusion tergolong tinggi. Fakta ini bisa menjadi salah satu penyebab mengapa skill keuangan tidak berpengaruh terhadap financial inclusion. Hal ini juga menunjukkan bahwa program literasi keuangan masyarakat masih perlu untuk 
dilakukan. Kedua, keterampilan yang diberikan kepada masyarakat mungkin tidak sesuai dengan kognitif mereka dan hal inilah yang menyebabkan dampak buruk dalam tindakan keuangan mereka (Okello et al, 2017). Pendapat ini dapat digunakan karena adanya beberapa kemiripan pada pola sampel dalam penelitian Okello et al. Keterampilan yang diberikan melalui program literasi keuangan terhadap masyarakat mungkin terlalu kompleks sehingga sulit dipahami dan diterima oleh masyarakat di pedesaan.

Hipotesis ketiga diterima, hal ini berarti attitude berpengaruh positif terhadap financial inclusion di pedesaan Bengkulu. Temuan ini mendukung hasil temuan dari beberapa peneliti sebelumnya antara lain Okello et al (2017), Willis (2008) dan Holzmann (2010). Menurut Okello et al (2017) tingkat kesadaran yang rendah tentang produk dan sikap keuangan dapat mengurangi permintaan mereka terhadap produk keuangan. Artinya semakin tinggi kesadaran masyarakat tentang produk dan sikap keuangan maka akan semakin tinggi pula permintaan akan produk keuangan. Permintaan yang meningkat akan memacu berdiri dan berkembangnya industri jasa keuangan di suatu wilayah yang akan meningkatkan financial inclusion dari dimensi akses dan kualitas.Sikap yang ditanamkan melalui literasi keuangan menyebabkan masyarakat berkeinginan untuk merencanakan keuangan pribadi mereka yang kemudian akan berdampak pada rencana tabungan dan pinjaman (Willis, 2008). Hal yang sama juga dikemukan oleh Holzmann (2010) bahwa sikap individu untuk menabung, meminjam atau menggunakan produk keuangan yang kemudian akan mempengaruhi inklusi keuangan.

Dan hasil yang terakhir menunjukkan bahwa behavior berpengaruh positif terhadap financial inclusion di pedesaan Bengkulu. Temuan ini sekaligus mendukung beberapa penelitian sebelumnya. Lusardi \& Mitchell (2014); Lusardi, Mitchell dan Curto (2010); Meier \& Sprenger (2010) dalam Okello et al (2017) mengemukakan bahwa tingkat literasi keuangan yang rendah dikaitkan tingkat penggunaan layanan keuangan alternatif yang lebih tinggi dan tingkat utang yang lebih tinggi. Sedangkan perilaku keuangan yang positif akan menunjukkan kemampuan mereka dalam menyusun anggaran dan tabungan dengan baik (Holzmann, 2010). Artinya semakin tinggi perilaku keuangan seseorang maka akan semakin tingg pula kemampuan pengelolaan keuangan dan tabungan yang pada akhirnya akan memicu pengambilan produk keuangan. Pengambilan produk keuangan ini meningkatkan financial inclusion dari dimensi penggunaan. Pada negara-negara berkembang, di mana mayoritas penduduk tidak memiliki akses terhadap layanan keuangan formal, program financial literacy dan intervensi mampu meningkatkan penggunaan produk seperti rekening tabungan dan asuransi (Xu dan Zia, 2012).

Hasil temuan pada hipotesis keempat ini juga mendukung Social Learning Theory, dimana terdapat hubungan timbal balik antara lingkungan, cognitif dan perilaku. Dalam penelitian ini lingkungan pedesaan yang memiliki tingkat literasi 
keuangan yang terus meningkat setiap tahunnya, mampu meningkatkan perilaku keuangan yang lebih positif. Tingkat literasi yang meningkat menunjukkan bahwa lingkungan tersebut diisi oleh orang-orang yang memiliki pengetahuan tinggi. Asumsinya jika masyarakat hidup di wilayah dengan tingkat literasi yang tinggi maka perilaku keuangan dan kognitif-nya juga akan menjadi baik. Perilaku keuangan yang baik dicerminkan oleh beberapa hal antara lain, perencanaan keuangan, penetapan tujuan keuangan, pengelolaan sumber daya keuangan dan penggunaan produk keuangan yang baik. Pada akhirnya semua ini akan berdampak pada tingkat kesejahteraan hidup masyarakat.

\section{KESIMPULAN DAN SARAN}

Berdasarkan hasil pengujian hipotesis dapat disimpulkan bahwa terdapat tiga hipotesis yang diterima dan ada satu hipotesis yang ditolak. Kesimpulan yang didapat dalam penelitian ini adalah variabel knowledge, attitude dan behavior berpengaruh terhadap financial inclusion di pedesaan Bengkulu sedangkan variabel skill tidak berpengaruh terhadap financial inclusion di pedesaan Bengkulu.

Beberapa upaya yang bisa dilakukan untuk meningkatkan literasi dan inklusi keuangan ialah dengan meningkatkan program edukasi dan kampanye mengenai literasi keuangan secara berkala, mengembangkan infrastruktur yang dibutuhkan untuk meningkatkan financial literacy dan financial inclusion kemudian menyediakan produk dan jasa yang sesuai dengan kebutuhan masyarakat. Bagi individu, sangat penting menerapkan pengelolaan keuangan yang baik terutama bagi mereka yang sudah pernah memperoleh pelatihan keuangan, karena pada dasarnya pengelolaan keuangan pribadi dapat membantu individu untuk mencapai kesejahteraan keuangan.

Pengelolaan keuangan dapat dilakukan dengan cara membuat daftar tujuan keuangan selama satu bulan, membuat catatan pengeluaran keuangan dan pemasukan keuangan secara terorganisir sehingga dapat dikelola dengan baik. Bagi masyarakat yang lebih suka menggunakan android dibandingkan dengan membuat catatan di buku, beberapa aplikasi android berikut ini dapat membantu mahasiswa dalam melakukan pencatatan keuangan seperti Money Lover, Money Manager dan lain sebagainya.

Penelitian ini juga masih memiliki beberapa kelemahan diantaranya yaitu teori yang masih lemah. Saran untuk penelitian selanjutnya agar bisa menggunakan teori yang lebih kuat lagi serta memperbanyak rujukan jurnal serupa. Lalu kelemahan kedua ialah penelitian ini hanya berfokus pada sektor perbankan, sebaiknya peneliti selanjutnya juga mempertimbangkan sektor jasa keuangan lainnya seperti pasar modal, asuransi dan lain sebagainya.

\section{DAFTAR PUSTAKA}


Atkinson, A. and F. Messy (2013), "Promoting Financial Inclusion through Financial Education: OECD/INFE Evidence, Policies and Practice", OECD Working Papers on Finance, Insurance and Private Pensions, No. 34, OECD Publishing, Paris. http://dx.doi.org/10.1787/5k3xz6m88smp-en

Bank Indonesia. (2014). Booklet Keuangan Inklusi. Jakarta: Departemen Pengembangan Akses Keuangan dan UMKM Bank Indonesia.

Braunstein, S., \& Welch, C. (2002). Financial Literacy: An Overview of Practice, Research, and Policy. Federal Reserve Bulletin November 2002.

Chaulagain, P, Ramesh. 2017. Relationship between Financial Literacy and Behavior of Small Borrowers. NRB Working Paper, NRB-WP-38.

Cohen, M., \& Nelson, C. (2011), 'Financial Literacy: A Step for Clients towards Financial Inclusion', Draft paper, Washington, DC.

Cole,S., Sampson, T., and Zia, B. (2009). Financial Literacy, Financial Decisions, and the Demand for Financial Services: Evidence from India and Indonesia

Holzmann, R. (2010). Bringing Financial Literacy and Education to Low and Middle Income Countries: The Need to Review, Adjust, and Extend Current Wisdom, World Bank, IZA and CES, available (online) http://erepository.uonbi.ac.ke:8080/xmlui/handle/123456789/9897,

Hussain, J., Salia, S., \& Karim, A. (2018). Is knowledge that powerful? Financial literacy and access to finance. Journal of Small Business and Enterprise Development. doi:10.1108/jsbed-01-2018-0021

Jappelli, T. (2010). Economic Literacy: An International Comparison*. The Economic Journal, 120(548), F429-F451. doi:10.1111/j.1468-0297.2010.02397.x

Kefela, T, G. (2010). Promoting access to finance by empowering consumers - Financial literacy in developing countries. Educational Research and Reviews Vol. 5 (5), pp. 205-212, March 2010 ISSN 1990-3839 @ 2010 Academic Journals.

Lusardi, A., Mitchell, O.S., \& Curto, V. (2010). "Financial Literacy among the Young."Journal of Consumer Affairs, 44(2): 358\{380.

Lusardi, A. \& Tufano, P. (2008). Debt Literacy, Financial Experience and Overindebtedness. Harvard School Working Paper.

Nkundabanyanga, S.K., Kasozi, D., Nalukenge, I., \& Tauringana, T. (2014)," Lending terms, financial literacy and formal credit accessibility ", International Journal of Social Economics, Vol. 41 Iss 5 pp. 342 - 361. Permanent link to this document: http://dx.doi.org/10.1108/IJSE-03-2013-0075

Okello, Candiya Bongomin, G., Munene, J. C., Ntayi, J. M., \& Malinga, C. A. (2017). Financial literacy in emerging economies: Do all components matter for financial inclusion of poor households in rural Uganda?. Managerial Finance, 43(12), 13101331. doi:10.1108/mf-04-2017-0117 
Otoritas Jasa Keuangan (2017). Strategi Nasional Literasi Keuangan Indonesia. Jakarta: Departermen Literasi dan Inklusi Keuangan Bidang Edukasi dan Perlindungan Konsumen.

Otoritas Jasa Keuangan (2016). Survei Nasional Literasi Keuangan dan Inklusi Keuangan. Jakarta: Departermen Literasi dan Inklusi Keuangan Bidang Edukasi dan Perlindungan Konsumen.

Pankow, Debra. 2003. Financial Values, Attitude and Goals. North Dakota State Univercity Fargo, North Dakota 58105.

Rakhmindyarto \& Syaifullah. (2013). Keuangan Inklusif dan Pengentasan Kemiskinan. https:// www.kemenkeu.go.id/media/4459/keuangan-inklusif-dan-pengentasankemiskinan.pdf,

Tustin, H., D. (2010). An impact assessment of a prototype financial literacy flagship programme in a rural South African setting. African Journal of Business Management Vol. 4(9), pp. 1894-1902, 4 August 2010 ISSN 1993-8233

Willis, E., L. (2008). Against Financial Literacy Education. Loyola University Law School, Los Angeles Legal Studies Research Paper No. 2008-13

Xu, L., \& Zia, B. (2012), Financial Literacy around the World: An Overview of the Evidence with Practical Suggestions for the Way Forward, Policy Research Working Paper No. 6107: The World Bank, Washington DC. 